\title{
Efektivitas Online Learning terhadap Kemampuan Pemecahan Masalah Matematika Mahasiswa
}

\author{
Dian Kusmaharti ${ }^{1}$, Via Yustitia ${ }^{2 *}$ \\ 1,2 Universitas PGRI Adi Buana Surabaya \\ *via.yustitia@unipasby.ac.id
}

Diterima: Mei 2020. Disetujui: Juni 2020. Dipublikasikan: Juli 2020.

\begin{abstract}
ABSTRAK
Masa pandemi Covid-19 mengharuskan mahasiswa tetap kuliah dari rumah. Online learning dapat dijadikan alternatif solusi untuk tetap melaksanakan pembelajara n. Tujua n penelitian ini adalah untuk mengetahui efektivitas pembelajaran matematika di PGSD, Universitas PGRI Adi Buana Surabaya melalui online learning. Kriteria efektif dalam penelitian ini adalah kemampuan pemecahan masalah mahasiswa memenuhi kriteria ketuntasan minimum dan respon mahasiswa terhadap pembelajaran dalam kategori po sit if. Penelitian ini merupakan penelitian kuantitatif. Metode yang digunakan tes dan angket. Data kemampuan pemecahan masalah dianalisis menggunakan uji proporsi pihak kanan. Data observasiaktivitas dan respon mahasiswa dianalisis secara deskriptif. Hasil penelitia n menunjukkan bahwa pembelajaran matematika melalui online learning efektif dilaksanakan di tengah pandemi covid-19. Hal ini ditunjukkan oleh kemampuan pemecahan masalah mahasiswa memenuhi kriteria ketuntasan minimum dan respon mahasiswa terhadap pembelajaran dalam kategori positif. Kendala yang sering terjadi adalah signal internet yang tidak selalu baik, beberapa mahasiswa kesulitan belajar mandiri dan diskusi kelompok. Seharusnya seorang dosen harus mempersiapkan perangkat pembelajaran online learning dengan baik sehingga hasilnyapun akan maksimal.

Kata kunci: covid-19, online learning, pembelajaran matematika.
\end{abstract}

\begin{abstract}
The Covid-19 pandemic period requires students to study at home. Online learning can be used as an alternative solution to continue implementing learning. The purpose of this study was to determine the effectiveness of mathematics learning at PGSD, PGRI Adi Buana University Surabaya through online learning. The effective criteria in this study are the students 'problem solving ability to meet the minimum mastery criteria and students' responses to learning in the positive category. This research is a quantitative research. The method used is test and questionnaire. Data of problem solving ability was analyzed using the proportion test. Student activity observation and response data were analyzed descriptively. The results showed that mathematics learning through online learning was effectively carried out during covid-19 pandemic. This is indicated by the problem-solving ability of students meeting the minimum mastery criteria and students' responses to learning in the positive category. The obstacle that often occurs are the internet signals are not always good, some students have difficulty learning independently and group discussions. It is recommended to lecturers to prepare online learning tools well so that the results will be maximal.
\end{abstract}

Keywords: covid-19, online learning, mathematics learning.

How to Cite: Kusmaharti, D. \& Yustitia, V. (2020). Efektivitas Online Learning terhadap Kemampuan Pemecahan Masalah Matematika Mahasiswa. Journal of Medives: Journal of Mathematics Education IKIP Veteran Semarang, 4(2), 311-318. 


\section{PENDAHULUAN}

Perkembangan pengetahuan dan teknologi saat ini semakin pesat memberi pengaruh dalam segala bidang kehidupan manusia. Komputer dan internet dapat dijadikan sarana untuk mempermudah aktivitas dalam kehidupan sehari-hari bukanlah hal yang baru. Komputer dan internet sangat diperlukan dalam penyajian informasi aktual. Pemanfaatan teknologi juga dapat dijadikan salah satu cara yang cukup efektif untuk menyampaikan materi pada proses pembelajaran (Bates, 2005; Jewwit, 2006; Buckingham, 2013; Lin \& Hwang, 2019; Fanny, 2019).

Pada masa pandemi Covid-19 di Indonesia, perguruan tinggi sebagai salah satu lembaga yang terdampak dari penyebaran covid-19. Direktur Jenderal Pendidikan Tinggi Kemendikbud mengeluarkan surat edaran tentang masa belajar dan penyelenggaraan program pendidikan selama darurat virus corona. Hal ini didasarkan pada Surat Edaran dari Menteri Pendidikan dan Kebudaya-an Nomor: 36962/MPK. A/HK/2020 tertanggal 17 Maret 2020 tentang Pembelajaran secara Daring dan Bekerja dari Rumah dalam rangka Pencegahan Penyebaran Corona Virus Disease (Covid-19). Terkait Surat tersebut, Dirjen Dikti juga menyampaikan bahwa mahasiswa diwajibkan untuk kuliah dari rumah.

Berbagai universitas telah memutuskan memfasilitasi kuliah dari rumah melalui online learning. Online learning merupakan pembelajaran yang memung-kinkan penyampaian materi ajar ke mahasiswa dengan memanfaatkan media internet atau media jaringan komputer lain (Anderson, 2008; You, 2016; Hartley, 2019; Kocacoban \& Cussens, 2020). Melalui online learning, maha-siswa dapat tetap nyaman belajar di rumah saat kondisi pandemic Covid-19 seperti sekarang ini. Setiap mahasiswa memiliki kebebasan belajar di tempat yang paling nyaman dengan kecepatan yang sesuai dengan daya tangkap masing-masing.

Beberapa manfaat yang diperoleh apabila menggunakan online learning antara lain: (1) belajar lebih fleksibel dan nyaman sehingga motivasi belajar lebih baik; (2) performa mahasiswa dapat dimonitor lebih mudah; (3) online learn-ing dapat digunakan sebagai sumber dan media pembelajaran; (4) pembelajaran menyenangkan (Stephenson, 2018). Emde, dkk (2020) mengemukakan bah-wa mampu membuat mahasiswa menda-patkan pengalaman baru dalam belajar memanfaatkan teknologi sehingga memungkinkan peningkatan kreativitas dan berpikir kritis.

Beberapa hasil penelitian menunjukkan bahwa online learning dapat meningkatkan hasil belajar siswa (Muali, dkk, 2018; Irwan, dkk, 2019; Anwar dan Ikawati, 2020). Selain itu, pembelajaran online learning juga dapat meningkatkan motivasi belajar siswa (Amin, 2017)

Pihak Universitas PGRI Adi Buana Surabaya telah memfasilitasi dosen dan mahasiswa untuk melaksanakan pembelajaran melalui Learning Management Sistem yang diberi nama VIRLENDA (Virtual Learning 
Environ-ment of Adi Buana). Online learning dapat dilakukan secara syncronous maupun asynchromous. Penggunaan berarti dosen dan mahasiswa terhubung dengan Virlenda dalam waktu bersama-an layaknya tatap muka, sedangkan asynchromous dosen dan mahasiswa tidak mengakses Virlenda dalam waktu bersamaan.

Kuliah dari rumah tentunya membawa sebuah problem baru bagi mahasiswa. Mahasiswa belum terbiasa melaksanakan pembelajaran tanpa tatap muka dan mahasiswa harus belajar mandiri. Mahasiswa wajib mempersiapkan kuota internet dan memilihi jaringan yang stabil untuk kelancaran online learning. Selain itu, tidak semua mahasiswa memiliki literasi digital yang baik, banyak mahasiswa yang merasa kesulitan menggunakan Virlenda. Oleh karena itu, dosen juga harus mempersiapkan desain online learning yang baik sehingga memudahkan mahasiswa. Berdasarkan latar belakang di atas, peneliti merasa perlu adanya kajian untuk mengetahui efektivitas online learning pada pembelajaran matematika ditengah pandemi Covid-19.

\section{METODE PENELITIAN}

Penelitian ini merupakan penelitian kuantitatif yang dilaksanakan di tengah pandemi Covid-19. Efektivitas dalam penelitian ini dilihat dari kemampuan pemecahan masalah matematika mahasiswa memenuhi ketuntasan klasikal dan respon mahasiswa terhadap pembelajaran online learning .

Populasinya adalah seluruh mahasiswa PGSD Angkatan 2019 yang terdiri atas tujuh kelas paralel, yaitu kelas 2019-A sampai 2019-G. Melalui teknik simple random sampling terpilih kelas 2019-A, 2019-B, dan 2019-C sebagai sampel penelitian. Pembelajaran menggunakan online learning diterapkan pada Mata Kuliah Konsep Matematika Lanjut pada Semester Genap 2019/2020.

Penelitian ini menggunakan metode tes dan angket. Metode tes digunakan untuk memperoleh data kemampuan pemecahan masalah, sedangkan metode angket untuk memperoleh data respon mahasiswa terhadap online learning.

Instrumen yang digunakan berupa soal tes uraian kemampuan pemecahan masalah yang terdiri dari 10 butir. Butir soal disesuaikan dengan capaian pembelajaran Mata Kuliah Konsep Matematika Lanjut. Soal kemampuan pemecahan masalah yang disusun disesuaikan dengan High Order Thinking Skills. Kunci jawaban dan pedoman penskoran mengacu pada langkah pemecahan masalah Polya. Sebelum soal diberikan tes divalidasi oleh ahli, kemudian diujicobakan di kelas 2019-F. Hasil uji coba menyatakan bahwa tes valid dan reliabel. Instrumen angket respon terdiri dari 15 butir pertanyaan. Mahasiswa diminta untuk memberikan respon terhadap keterlaksanaan pembelajaran online learning.

Analisis data tes menggunakan uji proporsi satu pihak (uji proporsi pihak kanan). Hipotesis dalam penelitian ini adalah tingkat keberhasilan belajar mahasiswa paling rendah $75 \%$ dari yang diharapkan, dengan nilai ketuntasan minimum 75. Sebelum dilakukan uji 
proporsi, peneliti melakukan uji prasyarat berupa uji normalitas. Analisis data dibantu dengan software SPSS. Data respon mahasiswa yang diperoleh dari pengisian angket atau kuisioner dianalisis dengan menentukan banyaknya yang memberi jawaban bernilai respons positif dan negatif untuk kategori yang ditanyakan dalam angket. Analisis data angket menggunakan kuantitatif deskriptif, menggunakan persentase.

\section{HASIL DAN PEMBAHASAN}

Penelitian ini dilaksanakan pada semester genap 2019/2020 di Program Studi Pendidikan Guru Sekolah Dasar. Bersamaan dengan pandemik Covid-19, pemerintah membuat kebijakan proses pembelajaran di perguruan tinggi dilaku-kan secara online. Peneliti menerapkan online learning dengan memanfaatkan Learning Management System (LMS). Pihak Universitas PGRI memberikan fasilitas LMS yang diberi nama Virlenda (Virtual Learning Environment of Adi Buana). Tampilan Virlenda pada pene-litian Ini ditunjukkan pada Gambar 1.

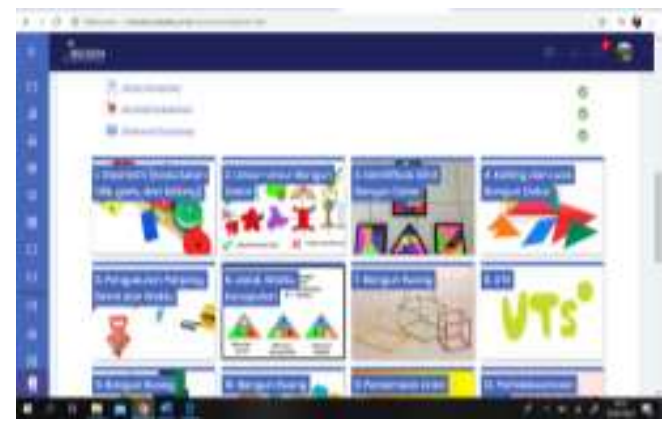

Gambar 1. Tampilan Virlenda

Melalui Virlenda, dosen dapat aktif berkomunikasi dua arah dengan mahasiswa. Fasilitas yang disediakan di
Virlenda cukup memadai, dosen dapat memberikan materi, media, video pembelajaran, dan buku referensi, terdapat forum diskusi, tugas, dan evaluasi. Pembelajaran dilakukan selama enam kali pertemuan dan satu kali tes kemampuan pemecahan masalah. Peneliti juga memberikan angket respon untuk diisi mahasiswa di akhir pembelajaran.

Hasil tes kemampuan pemecahan masalah matematika mahasiswa kelas 2019-A, 2019-B, dan 2019-C dideskripsikan pada Tabel 1.

Tabel 1. Deskripsi Hasil Tes

\begin{tabular}{lcccc}
\hline & N & Mean & $\begin{array}{c}\text { Mini- } \\
\text { mum }\end{array}$ & $\begin{array}{c}\text { Maxi- } \\
\text { mum }\end{array}$ \\
\hline Tes_2019A & 37 & 81.2703 & 66.00 & 90.00 \\
Tes_2019B & 37 & 80.5135 & 55.00 & 90.00 \\
Tes_2019C & 37 & 80.5946 & 60.00 & 92.00 \\
\hline
\end{tabular}

Berdasarkan Tabel 1, jelas bahwa untuk rata-rata kelas 2019-A, B, dan C berturut adalah 81,27; 80,51; dan 80,59. Sebelum dilakukan uji proporsi, dilakukan terlebih dahulu uji prasyarat berupa uji normalitas dengan uji Kolmogorovsmirnov. Hasil uji normalitas data tes kemampuan pemecahan masalah matematika mahasiswa kelas 2019-A, 2019-B, dan 2019-C dideskripsikan pada Tabel 2.

Tabel 2. Hasil Uji Normalitas

\begin{tabular}{llrrr}
\hline & & Tes_2019A & Tes_2019B & Tes_2019C \\
$\mathrm{N}$ & & 37 & 37 & 37 \\
\hline Normal & Mean & 81.2703 & 80.5135 & 80.5946 \\
Parame- & Std. Dev- & 6.74392 & 7.85147 & 7.13933 \\
ters ${ }^{\mathrm{a}, \mathrm{b}}$ & iation & & & \\
\hline Most & Absolute & .154 & .149 & .137 \\
Extreme & Positive & .142 & .113 & .101 \\
$\begin{array}{l}\text { Diffe- } \\
\text { rences }\end{array}$ & Negative & -.154 & -.149 & -.137 \\
\hline \multicolumn{7}{l}{ Test Statistic } & .154 & .149 & .137
\end{tabular}




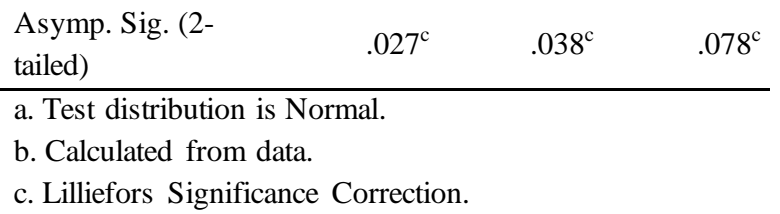

Berdasarkan Tabel 2, hasil uji nor-malitas data menunjukkan nilai Asymp. Sig tidak signifikan lebih besar dari 0.05, sehingga dapat disimpulkan data berasal dari populasi yang berdistribusi normal. Hasil uji hipotesis dalam penelitian ini ditunjukkan pada Tabel 3.

\begin{tabular}{|c|c|c|c|c|}
\hline \multirow[t]{2}{*}{ Kelas } & \multirow[t]{2}{*}{$\mathrm{t}$} & \multirow[t]{2}{*}{ df } & \multicolumn{2}{|c|}{$\begin{array}{l}\text { 95\% Confidence } \\
\text { Interval of the } \\
\text { Difference }\end{array}$} \\
\hline & & & Lower & Upper \\
\hline 2019_A & 73.303 & 36 & 79.0217 & 83.5188 \\
\hline 2019_B & 62.376 & 36 & 77.8957 & 83.1313 \\
\hline 2019_C & 68.667 & 36 & 78.2142 & 82.9750 \\
\hline
\end{tabular}

Berdasarkan Tabel 3, jelas bahwa untuk kelas 2019-A t hitung $=73.303$ dan tabel diperoleh dengan $\mathrm{df}=36$, sig $5 \%(1$ tailed $)=1.684$. Karena $-t$ tabel < dari $t$ hitung $(-1.684<73.303)$, maka Ho diterima, artinya tingkat keberhasilan kemampuan pemecahan masalah kelas 2019-A paling tinggi $75 \%$ tidak terbukti, bahkan lebih dari yang diduga yaitu sebesar 83.5188. Kelas 2019-B t hitung $=62.376 \mathrm{dan}$ tabel diperoleh dengan $\mathrm{df}=36$, sig $5 \%$ $(1$ tailed $)=1.684$. Karena $-t$ tabel $<$ dari t hitung (-1.684 < 62.376), maka Ho diterima, artinya tingkat keberhasilan kemampuan pemecahan masalah kelas 2019-B paling tinggi 75\% tidak terbukti, bahkan lebih dari yang diduga yaitu sebesar 83.1313. Kelas 2019-C t hitung $=68.667$ dan tabel diperoleh dengan $\mathrm{df}=36$, sig $5 \%$ (1 tailed $)=$
1.684. Karena $-\mathrm{t}$ tabel $<$ dari $t$ hitung (1.684 < 68.667), maka Ho diterima, artinya tingkat keberhasilan kemampuan pemecahan masalah kelas 2019-C paling tinggi $75 \%$ tidak terbukti, bahkan lebih dari yang diduga yaitu sebesar 82.9750.

Hasil angket respon mahasiswa terhadap online learning pada pembelajaran matematika ditunjukkan pada Tabel 4.

Tabel 4. Rekapitulasi Angket Respon Mahasiswa

\begin{tabular}{lcccc}
\hline & \multicolumn{2}{c}{$\begin{array}{c}\text { Rata-Rata } \\
\text { Jumlah }\end{array}$} & \multicolumn{2}{c}{$\begin{array}{c}\text { Rata-Rata } \\
\text { Persentase }\end{array}$} \\
\cline { 2 - 5 } & $\begin{array}{c}\text { Respon } \\
\text { Positif }\end{array}$ & $\begin{array}{c}\text { Respon } \\
\text { Negatif }\end{array}$ & $\begin{array}{c}\text { Respon } \\
\text { Positif }\end{array}$ & $\begin{array}{c}\text { Respon } \\
\text { Negatif }\end{array}$ \\
\hline $\begin{array}{l}\text { Kelas } \\
\text { 2019-A }\end{array}$ & 13,09 & 2,91 & 81,82 & 18,18 \\
$\begin{array}{l}\text { Kelas } \\
\text { 2019-A } \\
\text { Kelas } \\
\text { 2019-A } \\
\text { Rata- }\end{array}$ & 12,95 & 3,05 & 80,94 & 19,06 \\
rata & 12,94 & 3,06 & 80,89 & 19.11 \\
\hline
\end{tabular}

Berdasarkan Tabel 4 persentase rata-rata mahasiswa yang memberikan respon positif adalah $81,22 \%$. Hal ini berarti setiap aspek direspon positif oleh mahasiswa sehingga online learning berjalan cukup baik berdasarkan respon mahasiswa. Hasil analisis angket respon mahasiswa menunjukkan bahwa: (1) perhatian mahasiswa setelah melaksanakan online learning pada pembelajaran matematika baik; (2) mahasiswa senang mengikuti online learning pada pembelajaran matematika; (3) online learning pada pembelajaran matematika dapat membuat mahasiswa dapat memahami materi; (4) online learning pada pembelajaran matematika merupakan hal yang baru bagi mahasiswa, karena selama ini 
lebih banyak tatap muka; (5) latihan soal dalam forum diskusi dan evaluasi dapat membantu mahasiswa dalam berlatih menyelesaikan soal-soal pemecahan ma-salah; (6) media pembelajaran, bahasa, penampilan tulisan, serta gambar yang digunakan dalam online learning pada pembelajaran matematika mudah dipahami dan menarik perhatian.

Pada Virlenda tersedia fasilitas tugas dan evaluasi yang harus dikerjakan mahasiswa. Setelah mengerjakan tugas tersebut, dosen memberikan nilai, dan mahasiswa mengetahui nilai yang diper-oleh. Pelaksanaan evaluasi di online learning ini menumbuhkan motivasi mahasiswa untuk memperoleh nilai yang baik. Sejalan dengan itu, Özhan \& Kocadere, (2020) mengatakan bahwa online learning berpengaruh terhadap kecerdasan emosional dan meningkatkan motivasi untuk sukses dalam pemecahan masalah.

Mahasiswa menyatakan perasaan senang terhadap online learning melalui Virlenda. Mahasiswa juga menyatakan kebaruan dari online learning pada pem-belajaran matematika yang digunakan. Mahasiswa mampu memaksimalkan penggunaan Virlenda untuk kuliah dari rumah pada masa pandemi Covid-19 ini.

Online learning pada pembelajaran matematika merupakan pembelajaran tanpa tatap muka dengan memanfaatkan Virlenda yang mudah diterapkan, melibatkan aktivitas seluruh mahasiswa tanpa harus ada perbedaan status, melibatkan peran mahasiswa sebagai tutor sebaya, dan terdapat evaluasi untuk mengukur keberhasilan.

Melalui Virlenda, mahasiswa terbiasa menyelesaikan tugas berupa latihan pemecahan masalah sehingga Online learning dapat efektif. Menurut Via (2015), kemampuan pemecahan masalah siswa dapat diperbaiki melalui latihan intensif. Berikut contoh aktivitas diskusi dan latihan pemecahan masalah matematika mahasiswa dalam Virlenda.

Aktivitas belajar dengan online learning memungkinkan mahasiswa dapat belajar lebih rileks di samping menumbuhkan tanggung jawab dan kemandirian belajar. Hal ini sejalan dengan hasil penelitian Sutisna (2016) bahwa pembelajaran online learning dapat meningkatkan kemandirian belajar. Al Aslamiyah, dkk (2019) juga menyatakan bahwa mahasiswa yang memanfaatkan online learning kemandirian belajarnya berada pada kategori positif. Berdasarkan hasil penelitian di atas, jelas bahwa online learning dapat efektif pada pembelajaran matematika di tengah pandemi Covid-19.

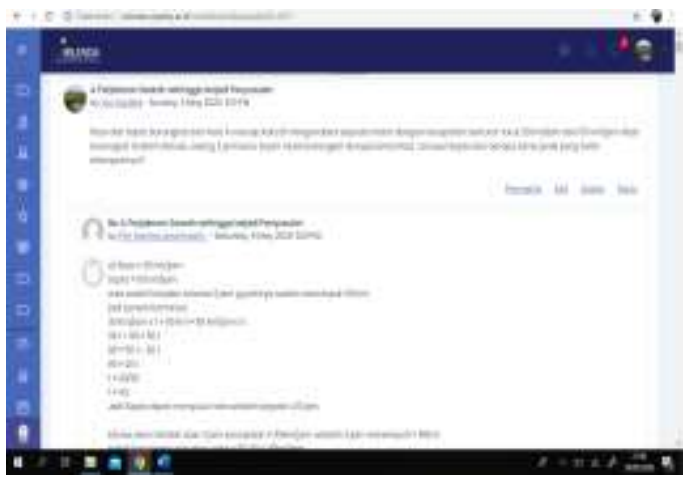

Gambar2. Aktivitas Diskusi Pemecahan Masalah 
Pembelajaran matematika melalui online learning efektif dilaksanakan di tengah pandemi covid-19. Hal ini ditunjukkan oleh kemampuan pemecahan masalah mahasiswa memenuhi kriteria ketuntasan minimum dan respon mahasiswa terhadap pembelajaran dalam kategori positif. Kendala yang sering terjadi adalah signal internet yang tidak selalu baik, beberapa mahasiswa kesulitan belajar mandiri dan diskusi kelompok. Seharusnya seorang dosen harus mempersiapkan perangkat pem-belajaran online learning dengan baik sehingga hasilnya pun aka maksimal.

\section{DAFTAR PUSTAKA}

Anwar, Z., \& Ikawati, H. D. (2020). Penerapan Online Learning (Studi Kasus di Prodi Teknologi Pendidikan Fakultas Ilmu Pendidikan dan Psikologi dan Psikologi Undikma). JURNAL CAHAYA MANDALIKA (JCM) eISSN 2721-4796, 1(1), 1-12.

Amin, A. K. (2017). Kajian Konseptual Model Pembelajaran Blended Learning berbasis Web untuk Meningkatkan Hasil Belajar dan Motivasi Belajar. Jurnal Pendidikan Edutama, 4(2), 51-64.

Al Aslamiyah, T., Setyosari, P., \& Praherdhiono, H. (2019). Blended Learning Dan Kemandirian Belajar Mahasiswa Teknologi Pendidikan. Jurnal Kajian Teknologi Pendidikan, 2(2), 109114.

Anderson, T. (Ed.). (2008). The theory and practice of online learning. Athabasca University Press.
Bates, A. W., \& Bates, T. (2005). Technology, e-learning and distance education. Psychology Press.

Buckingham, D. (2013). Beyond technology: Children's learning in the age of digital culture. John Wiley \& Sons.

Emde, R. J., Doherty, E. K., \& Flynt, D. (2020). Relationships in Online Learning Experiences: Identifying and Creating Positive Relationships in Online Learning. In Handbook of Research on Creating Meaningful Experiences in Online Courses (pp. 140-152). IGI Global.

Fanny, A. M. (2019, March). Analysis Of Pedagogical Skills And Readiness Of Elementary School Teachers In Support Of The Implementation Of The 2013 Curriculum. In International Conference on Bussiness Law and Pedagogy (Vol. 1, No. 1, pp. 5963).

Hartley, R. S., \& McGuire, P. G. (2019). Modified team-based learning as a weekly formative review. The FASEB Journal, 33(1_supplement), 606-6.

Irwan, I., Luthfi, Z. F., \& Waldi, A. (2019). Efektifitas Penggunaan Kahoot! untuk meningkatkan hasil belajar siswa. PEDAGOGIA: Jurnal Pendidikan, 8(1), 95-104.

Jewitt, C. (2006). Technology, literacy and learning: A multimodal approach. Psychology Press.

Kocacoban, D., \& Cussens, J. (2020). Fast Online Learning in the Presence of Latent Variables. Digitale Welt, 4(1), 37-42.

Lin, H. C., \& Hwang, G. J. (2019). Research trends of flipped 
classroom studies for medical courses: A review of journal publications from 2008 to 2017 based on the technology-enhanced learning model. Interactive Learning Environments, 27(8), 1011-1027.

Muali, C., Islam, S., Bali, M. E. I., Baharun, H., Mundiri, A., Jasri, M., \& Fauzi, A. (2018, November). Free Online Learning Based On Rich Internet Applications; The Experimentation of Critical Thinking About Student Learning Style. In Journal of Physics: Conference Series (Vol. 1114, No. 1, p. 012024). IOP Publishing.

Özhan, Ş. Ç., \& Kocadere, S. A. (2020). The effects of flow, emotional engagement, and motivation on success in a gamified online learning environment. Journal of Educational Computing Research, 57(8), 2006-2031.
Stephenson, J. (Ed.). (2018). Teaching \& learning online: new pedagogies for new technologies. Routledge.

Sutisna, A. (2016). Pengembangan Model Pembelajaran Blended Learning pada Pendidikan Kesetaraan Program Paket C dalam Meningkatkan Kemandirian Belajar. JTP-Jurnal Teknologi Pendidikan, 18(3), 156168.

Via, Y. (2015). Peningkatan Kemampuan Pemecahan Masalah Melalui Pengembangan Lembar Kegiatan Siswa (LKS) dengan Pendekatan Saintifik. Wahana, 64(1), 49-57.

You, J. W. (2016). Identifying significant indicators using LMS data to predict course achievement in online learning. The Internet and Higher Education, 29, 23-30. 